\title{
Subtitling as a Vector for the Promotion of Bilingualism and Patriotism
}

\author{
${ }^{1}$ Ayonghe Lum Suzanne (PhD), 'Besong Godson Enowmbi \\ ${ }^{1}$ Associate Professor of Audiovisual Translation, Advanced School of Translators and Interpreters \\ (ASTI) University of Buea, P.O. Box 63, Buea, South West Region, Republic of Cameroon \\ Email: ayonghelumsuzanne@gmail.com / s ayonghe@yahoo.com,Tel: +237 677744862. \\ ${ }^{2}$ Freelance Translator, Buea, South West Region, Republic of Cameroon \\ Email: godsonbesong2@gmail.com,Tel: +237 674572103.
}

${ }^{1}$ Corresponding author

\begin{abstract}
This paper is aimed at showing that subtitling can be used to foster bilingualism and patriotism in Cameroon. The objectives are to investigate how deeply rooted the practice of audiovisual translation is in local media outlets, focusing on how it can help in promoting bilingualism; promote the use of subtitling in the Cameroonian audiovisual media landscape; and assess the pivotal role of the audiovisual translator in this sector. A sample of 151 persons was used. Questionnaires were administered to respondents and stakeholders were interviewed in two media houses: Hi TV and CRTV. Hi TV is based in an English-speaking region, and CRTV is a State-owned media house and believed to have the widest audience in the country. Findings revealed that subtitling does not only provide TV viewers with information in their second official language, but also enables them to improve on their reading and writing skills, as well as their bilingualism, among others. Subtitling is not advanced in media houses in Cameroon. Recommendations were made to improve on the practice of subtitling in media houses in Cameroon. These include increasing the level of subtitled programmes broadcast on TV stations, raising awareness on the importance of media information access by the hearing impaired; creating an audiovisual translation unit in each TV broadcasting house and recruiting audiovisual translators; voting of laws to make the subtitling of some, if not, all TV programmes broadcast by Cameroonian TV channels mandatory; educating the public on the importance of subtitling by gradually introducing them to viewers through TV programmes, so that their eyes and mind could progressively get used to watching subtitled material and thus avoid total rejection of the subtitles; and training more audiovisual translators in Cameroon.
\end{abstract}

Key words: Translation, Bilingualism, Patriotism, Vector, Subtitling

Received: 26/ 02/ 2021

Accepted: 20/ 03/ 2020

D OI: https/ / dx.doi.org/ 10.4314/ jcas.v16i2.6

(c) The Authors. This work is published under the Creative Commons Attribution 4.0 International Licence. 


\section{Résumé}

Cet article vise à montrer que le sous-titrage peut être utilisé pour promouvoir le bilinguisme et le patriotisme au Cameroun. Les objectifs sont d'étudier l'enracinement de la pratique de la traduction audiovisuelle dans les médias locaux, en se concentrant sur la manière dont elle peut contribuer à la promotion du bilinguisme ; de promouvoir l'utilisation du sous-titrage dans le paysage audiovisuel camerounais ; et d'évaluer le rôle central du traducteur audiovisuel dans ce secteur. Un échantillon de 151 personnes a été utilisé. D es questionnaires ont été administrés aux répondants et les parties prenantes ont été interviewées dans deux maisons de médias : Hi TV et CRTV. Hi TV est basée dans une région anglophone, et la CRTV est un média d'État, censé avoir la plus large audience du pays. Les résultats ont révélé que le sous-titrage ne fournit pas seulement aux téléspectateurs des informations dans leur deuxième langue officielle, mais leur permet également d'améliorer leurs compétences en lecture et en écriture, ainsi que leur bilinguisme, entre autres. Le sous-titrage n'est pas très répandu dans les médias camerounais. D es recommandations ont été faites pour améliorer la pratique du sous-titrage dans les médias camerounais. Elles comprennent l'augmentation du nombre de programmes sous-titrés diffusés sur les chaînes de télévision, la sensibilisation à l'importance de l'accès des malentendants à l'information médiatique, la création d'une unité de traduction audiovisuelle dans chaque maison de télédiffusion et le recrutement de traducteurs audiovisuels, le vote de lois pour rendre obligatoire le sous-titrage de certains, sinon de tous les programmes télévisés diffusés par les chaînes de télévision camerounaises ; l'éducation du public sur l'importance du sous-titrage en le présentant progressivement aux téléspectateurs à travers les programmes télévisés, afin que leurs yeux et leur esprit puissent s’habituer progressivement à regarder des documents sous-titrés et ainsi éviter un rejet total des sous-titres ; et la formation davantage de traducteurs audiovisuels au Cameroun.

Mots clés : Traduction, Bilinguisme, Patriotisme, Vecteur, Sous-titrage 


\section{Introduction}

Cameroon was partitioned at the League of Nations and handed over to Britain and France for administration in 1915, following the defeat of Germany. These two countries administered their respective territories (British Cameroons and French Cameroon) until February 11, 1961 when, following a plebiscite organized by the United Nations Organization (UNO), 70.49\% British Southern Cameroonians voted massively to reunite with their brothers of La Republique du Cameroun to form a single nation (Awasom, 2000). From that time and given the fact that there had been a merger of two linguistic cultures, Cameroon became a bilingual nation, having as official languages English and French as inscribed in Article 1 section 3 of its Constitution "The Official languages of the Republic of Cameroon shall be English and French, both languages having the same status. The State shall guarantee the promotion of bilingualism throughout the country." Since the respect of the Constitution is one of the greatest marks of patriotism which a citizen can show proof of, the government of Cameroon has been looking for means and ways to preserve and promote this linguistic blend, which will enable Cameroonians know each other better and feel more proud of this linguistic specificity that is part and parcel of their national legacy. Though its efforts are numerous, results are still to be felt since bilingualism in Cameroun is more of a slogan than the reality.

As Neves (2005:15) puts it, for an individual to fully participate in our modern 'information society, they must have full access to all available communication and information channels. Fortunately, broadcasting in Cameroon began way back in 1941 with the first radio station "la société de radio-diffusion de la France $\mathrm{O}$ utre Mer (SORAFOM)", introduced during the Second World War when the French arrived in Douala and installed short wave transmission (https:// www.crtv.cm/ ). Television came 25 years after independence that is in 1985, with the creation of the Cameroon Television (CTV), which was later merged with radio to form the Cameroon Radio Television Corporation (CRTV) on 17 December 1987.

Furthermore, Cameroon being a bilingual country, broadcasting is expected to be done in the two official languages of the State and in a comprehensive, fair and balanced manner that will make information available to the two linguistic strata in the nation. How best can this be achieved if not through translation in general and audiovisual translation (AVT) in particular? Given that AVT's main objective is to bridge gaps that may derive from linguistic problems (Nerves, 2005), it has thus been undergoing a revolution which Diaz Cintas (2003:193) attributes to "the explosion in the number of channels, diversification of televisual means, greater demand for distant learning, technological progress and presence of multimedia products in our daily lives".

In order to promote this bilingualism which will have an impact on the level of patriotism of Cameroonians, the government has, for years now, been making use of several mechanisms such as the National Commission for the Promotion of Bilingualism and Multiculturalism (NCPBM), charged with the task of bringing forth ideas that will permit Cameroonians live together and preserve their cultural and linguistic heritage. Mindful of the fact that bilingualism is part and parcel of this legacy which must be preserved, Cameroonians in general and scholars in particular have the duty and primordial task of researching in all domains which can contribute in this direction. It is against this backdrop that this study is undertaken, with the aim of bringing forth pertinent solutions for the fostering of this cherished legacy, that is, bilingualism in Cameroon. 


\subsection{Statement of the problem}

In line with the above-mentioned considerations, it would appear that the audiovisual needs of the two linguistic strata of the country are hardly being satisfied. It has been observed that the practice of subtitling is practically inexistent in almost all audiovisual broadcasting stations in Cameroon, in all broadcasting media in Cameroon, including the public broadcasting media, CRTV. This study is therefore concerned with how bilingualism can be fostered in Cameroon using the AVT mode known as subtitling, which is rapidly gaining grounds the world over.

\subsection{0 bjectives of the study}

The objectives of this study are to:

i. Investigate how deeply rooted the practice of audiovisual translation is in local media outlets, focusing on how it can help in promoting bilingualism and thus patriotism;

ii. Promote the use of subtitling in the Cameroonian audiovisual media landscape; iii. Assess the pivotal role of the audiovisual translator in this sector;

\subsection{Subtitling}

Subtitling used in any language is a wonderful way to enable people enjoy films and or programmes from other cultures. But for language learners, subtitling is a means to acquire language and comprehension. According to Diaz Cintas and Ramael (2007:8) "subtitling may be defined as a translation practice that consists of presenting a written text, generally written on the lower part of the screen, that endeavours to recount the original dialogue of the speakers, as well as the discursive elements that appear in the image (letters, inserts, graffiti, inscriptions, placards, and the like), and the information that is contained on the soundtrack (song, voices-off)".

Ayonghe (2009) carried out a study on the use of subtitling as a potential tool for the promotion of bilingualism and multilingualism in Cameroon using related technologies and equipment in terms of cost-effectiveness. The results of the study indicated that the use of bilingual subtitles (English \& French) will effectively improve the mastery of these languages and thus improve bilingualism. The results of the study also indicated that the approach was useful in achieving multilingualism by using subtitles with some of the major vernacular languages especially if the approach involved the broadcast of interlingual subtitles (English \& a major vernacular) once a month for about 30 minutes. Ayonghe's study (2009) differs from the current study in terms of the methodology used: it was a qualitative study based on field notes with observations, personal experience and documentation. While the current study effectively used questionnaires, interviews, observation and documentation. However, since 12 years later, interlingual subtitling is still not implemented in broadcasts as expected, the present study assesses the use of subtitling as a vector for the promotion of bilingualism and patriotism. It is accordingly a topical issue as well as a follow up of the work by Ayonghe (2009).

The importance of subtitling in enhancing communication, promoting bilingualism and multilingualism, as seen above, cannot be overemphasized. Bearing this in mind, one wonders why Cameroon seems not to have given much thought about the true potential of subtitling, but rather appears to stand at the same spot it was in 2009, when Ayonghe (2009) clearly demonstrated the importance of subtitling. From this observation, it appears no visible change has taken place since this period as regards the practice of subtitling and almost no effort is being made to change this situation in the near future. It should also be noted that the future of subtitling in the country will depend among other factors on studies carried out in the field by researchers 
as well as on the government and people's awareness of the benefits and potential uses of subtitling, and finally on the interest television stations have on issues of subtitling (Ayonghe, 2009).

Ayonghe and Tiokou (2018) carried out a similar research with the aim of analysing the prospects and challenges of subtitling as a mode of audiovisual translation in Cameroon. The objective of that study was to determine the role of subtitling in increasing literacy. For this reason, a wide range of students comprising forty-five (45) males, and fifty-five (55) females took part in this study at the University of Buea. They were administered questionnaires and the results indicated that subtitling promotes the linguistic capacity building of viewers. In addition, the above-mentioned study is similar to the present paper in the sense that, both studies are aimed at assessing to what extent subtitling can be used to improve on the linguistic capacity building of viewers.

Also, Costales (2017) in his article entitled "Subtitling in CLIL: promoting bilingual methodologies through audiovisual translation" tries to explore the use of subtitling as a teaching tool to promote bilingual methodological strategies in Content and Language Integrated Learning (CLIL). According to him, "subtitling as a didactic resource in CLIL - and in bilingual education in general - has been neglected so far, probably due to the stigmatization of translation in foreign language teaching and its association with the Grammar Translation method". In this light, he posits that translation can

help improve on students' language awareness and challenge language separation in bilingual education namely: the introduction of subtitling in CLIL is intended to encourage code-switching or translanguaging (i.e. the purposeful alternation of the L1 and L2) by working with inter- and intra- linguistic subtitles, enhancing students' metalinguistic skills and leading to the natural use of linguistic codes in the classroom.

According to Costales (2017), watching subtitled excerpts (videos) and producing subtitles in the first language and the L2 can promote bilingualism since these contents specific will be presented with the support of audiovisual material and cognition, communication, and intercultural elements will be endorsed in the two languages. Ntowa and Ayonghe (2015) demonstrated that AVT can successfully be used to teach English Language to French-Speaking students in Cameroon. Ayonghe and Mbele (2015) also proved that subtitling can effectively be used in the promotion of local languages in Cameroon. There is therefore no doubt about subtitling and its relevant role in bilingualism. Consequently, the study investigates the pertinent role of subtitling as a tool for the promotion of bilingualism in the country, with the aim of responding to the abovementioned suggestions.

\subsection{Bilingualism}

The definition of bilingualism is complex and influenced by multiple factors, such as the age of acquisition of the second language (L2), continued exposure to the first language (L1), relative skill in each language and the circumstances under which each language is learned. According to Valdez and Figueora (1994), bilingualism can be defined in simplest form as "knowing" two languages. Popular definitions of bilingualism conceptualize language knowledge as being a binary category, whether one is classified as having acquired two languages or not ( $\mathrm{G}$ rant \& $\mathrm{G}$ ottardo, 2004). However, bilingualism should be thought of as being a continuum where one can have varying levels of proficiency in two languages, regardless of how and when they are acquired. In addition, language and literacy skills are comprised of multiple subskills. In any given language, bilinguals might be highly proficient in one domain 
of skills but not in the other. For example, a person might show high oral language skills and limited reading skills. The Anglophone crisis that started in 2016 has made it clear that the linguistic inequity in Cameroon is a serious issue which needs a rapid and efficient response; Anglophones are glued to the English language as Francophones are to the French language. The natural inequality in Cameroon's linguistic landscape due to its colonial history made the English-speaking minority feel marginalized in several aspects concerning nation building, be it concerning the educational, or the judicial domain. This caused teachers and lawyers to undertake a strike action, since they had the feeling that their linguistic heritage and culture was in the process of being completely suppressed by their French-speaking counterparts.

\subsection{Patriotism}

Patriotism is defined by the Webster dictionary as "love for or devotion to one's country". Patriotism in this study means supporting and loving one's country even when it's going through rough or difficult times. The country is still loved, even when things are not as one desires or one would like. Subtitling is facing a sociopolitical crisis, which stems from the observation that many Cameroonians no longer have that feeling of belonging because they have for many years been attached to their L1, having little or no contact with their L2. Therefore, promoting bilingualism which is part of the linguistic legacy of their nation, will definitely strengthen their attachment to their L2 and defacto their nation. Even though there are other factors that affect patriotism, the linguistic aspect for the case of Cameroon is primordial, giving its linguistic background.

Several previous studies have argued that subtitles in audiovisuals can facilitate other aspects of second language learning such as vocabulary acquisition, or overall plot comprehension. For instance, Vulchanova et al (2015) claimed that both intra and interlingual subtitles result in improved plot comprehension and vocabulary learning. Markham and Peter (2001) investigated the effects of using Spanish caption, English captions (interlingual subtitles) or no captions on 213 intermediate universitylevel SFL students, with a view to examine their listening/ reading comprehension and revealed that interlingual subtitles were more beneficial for the students' reading/ listening comprehension than intralingual subtitles.

Armstrong et al (2017:33) now consider subtitles as "an integral part of the television service provided on all BBC programmes in the UK via digital television services and are used by around $10 \%$ of the viewing audience every day." This paper attempts to do a comparison on the respect of subtitle norms between web subtitles and television subtitles and concludes that TV subtitles are most not very accurate since their subtitles "do not always respect subtitling norms as compared to web subtitles which they are more accurate". A comparison was made on aspects such as subtitle positioning on a web video and that on a TV video and the font size of the subtitles. The results proved that these aspects are mostly respected when it comes to web videos.

\section{Materials and Methods}

This study focused on local media outlets and more precisely their audiovisual and subtitling department. This study was carried out in Buea and Yaounde and two TV channels (CRTV and HiTV) were used. A good number of respondents aged 20 and above made up of students and stakeholders of the audiovisual sector comprising 53 male and 90 female respondents took part in this study in the cities of Yaounde and Buea. Variables used here were sex, age group, the linguistic background and the level of education. 
From a linguistic point of view, the population used in the study was made up of two groups: 87 Anglophones and 56 Francophones, since the issue of bilingualism treated in this study concerns both linguistic strata. L1 and L2 here represented the first and second official languages respectively. So, Anglophones had the English language as their L1 and the French language as their L2, and vice versa for Francophones.

\subsection{Data Collection}

Data were collected through questionnaires, interviews, observation and documentation.

\subsubsection{Questionnaires}

O ne type of questionnaire was designed. It was meant for the general public, or at least those who fulfilled the criteria required to partake in the study. To identify the pertinent role subtitling could play in fostering bilingualism in Cameroon, it was necessary to seek the opinions of persons of all walks of life, but with a given educational level and also persons from both English and French linguistic backgrounds. The questions were aimed at finding out the television viewing habits of the respondents, their favourite programmes, their knowledge and preference of subtitling, why and how relevant they considered subtitling, as well as if they think subtitled programmes could help improve on their second official language. This was done in order to assess the role subtitling plays in enhancing bilingualism and patriotism in Cameroon and also guaranteeing access to media information for tele viewers of both linguistic backgrounds.

\subsubsection{Interviews}

O ne main interview guide was prepared and it was reserved for stakeholders at CRTV and $\mathrm{Hi}$ TV. This guide served the purpose of gathering information about the practice of subtitling in the media house, the role of translators and subtitlers in the audiovisual sector and how CRTV and Hi TV can bridge linguistic barriers to media accessibility of English and French speaking viewers in Cameroon.

Data analysis was done based on the Jakobson model (1963) to describe the spread of subtitling as a vector for the promotion of subtitling in Cameroon and through Excel. Both qualitative and quantitative methods were used. Results presented as percentages and charts.

\subsubsection{Observation}

O bservation was a key factor in this research. It was one of the ways through which the research questions were raised at the beginning and continued to be an important means of obtaining information. The media houses were particularly observed. The researcher took part in the subtitling of their news interview during which questions were interactively asked to the subtitlers with the aim of knowing how effectively audiovisual translators there carry out theirjob. It was observed that the subtitlers at both media houses did not respect the norms and when asked why, the answer was that "the most important thing is that the message goes across". A lot of observation was also done during interviews and while administering questionnaires. The impressions from observation are believed to be very useful in certain areas and on certain issues treated under data presentation. Also, programmes broadcast over the national station were watched in order to be aware of any modifications or developments that come up in the course of the study.

\subsubsection{Documentation}

Reference documents were consulted for information on the field from the library as well as online. Both hard copy and electronic documents were consulted. Brochures were read and websites of the various targeted schools were visited in order to know the origins of these institutions. Other reference materials like books were consulted for some relevant statistics. 


\section{Results}

This section presents results from questionnaires, interviews, observation and documentation.

\subsection{Results from questionnaires}

One hundred and forty-three $(75.5 \%)$ persons responded to the questionnaires administered. Eight others took part in the study through interviews. Ninety-nine percent (99\%) of the respondents watch TV in Cameroon. The lone respondent who had a "No" as answer justified his response by saying that he did not have a television. Nearly all (90\%) of the respondents know what subtitling is all about. Many had watched a subtitled programme on TV (87\%). O ut of this number, $94.7 \%$ were respondents of all walks of life and 5.3\% were CRTV and $\mathrm{Hi}$ TV personnel. They are grouped into the following age brackets: 20-30, 31-40 and 41 and above. Details of this distribution including educational level and linguistic background are presented in the figures 1, 2 and 3.

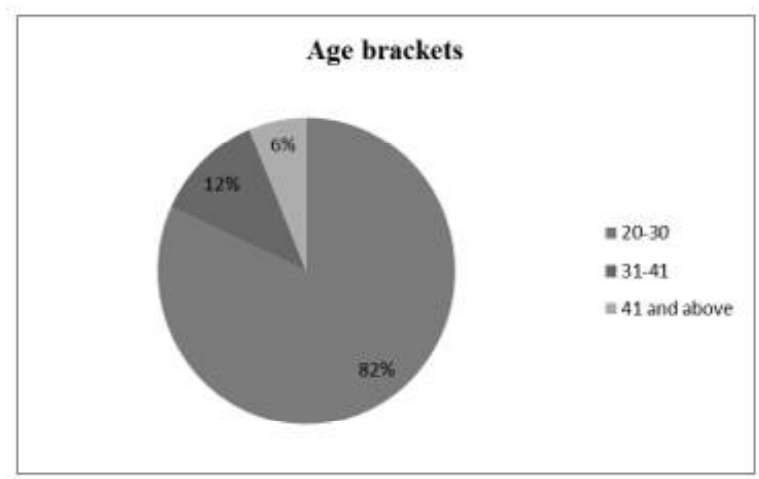

Figure 1: Age bracket [20-30 (82\%)]; [31-41 (12\%)]; [41 and above (6\%)]

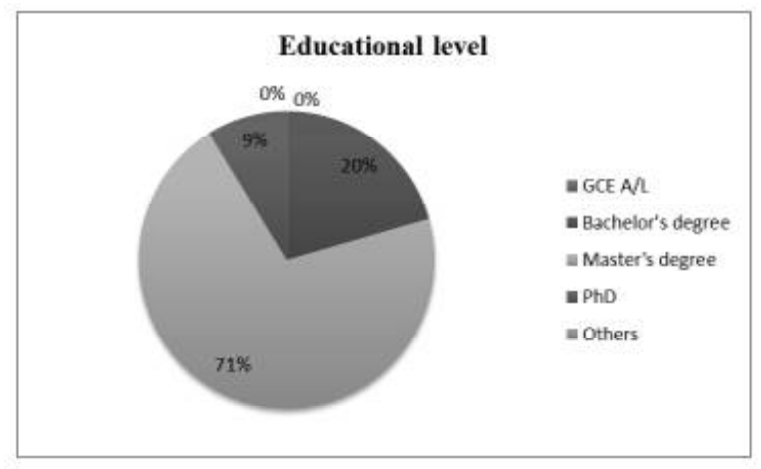

Figure 2: Level of education of respondents [GCE A/ L $(0 \%)]$; [Bachelor's degree (20\%)]; [Master's degree (71\%)]; $\mathrm{PhD}(9 \%)]$; [O thers $(0 \%)]$

\section{Linguistic background}

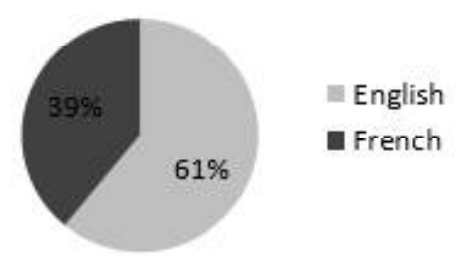

Figure 3: Linguistic background

Ayonghe and Djomo (2015) earlier showed that CRTV had a higher audience than other television channels in Cameroon, and this same observation is made in this study, based on the above results. This thus reveals how much impact CRTV can have on the Cameroonian audience if it increases its practice of subtitling (59\% watch CRTV followed by Equinox TV with $20 \%$, Canal 2 13\% and Hi TV 8\%). Favourite programs watched are: documentaries $(45 \%)$, news $(30 \%)$, talk shows (15\%) and film (10\%). They watch these programs mainly for infotainment (46\%), entertainment (25\%), information (20\%) and education (9\%).

\subsubsection{Reason for choice of television programmes}

This subsection is part of the results from questionnaires. It is used here to confirm the fact that showing subtitled programmes in most preferred areas of the viewers will be effective in acquiring their bilingualism. Tawah (2010) earlier proved that the main reason why people watch TV was for education, entertainment and information. This turns out to still be the same trend today. As such, it is believed that if these kinds of programmes are subtitled in the second official language to that in which they are broadcast, they will have a very significant impact on the viewers in terms of education, information and entertainment too. Nevertheless, it is observed that subtitling programmes like news that are most often aired live is quite a difficult task. However, if the headlines and major points are subtitled, then it is a first step in the right direction. 


\subsubsection{Language of the subtitles}

This question sought to find out whether the programmes which the respondents said they had watched were subtitled in their second official language (L2). This question was very relevant since this response will have a direct impact in demonstrating one of the hypotheses of this study which was that the subtitling of TV programmes on Cameroonian TV channels in the second official language from the one in which they are being broadcast will help Cameroonians improve on their L2, thereby enhancing their level of bilingualism. Respondents were expected to answer either by "yes" or "no" to this question and the results gotten were as follows: $91 \%$ responded by "yes", and only 9\% responded by "no".

\section{Language elements acquired after watching the subtitled programmes}

This question sought to find out what linguistic elements the respondents thought they had acquired as a result of watching subtitled programmes, in addition to ordinary programmes taught to these respondents in their schools. It is assumed that the use of subtitling is an additional tool since these respondents receive other information through normal learning methods. In other words, adding subtitles to what is being viewed and heard, will speed up the learning process. The results were as follows: $\mathrm{O}$ ut of the 143 respondents, $57 \%$ are of the opinion that Semantics is the aspect of language which they greatly acquired after watching these subtitled programmes. The fact that these subtitles could enable them associate the meaning of what was written to what was being said in the programmes could account for this choice. $20 \%$ of the respondents were of the opinion that lexicon is the linguistic aspect which they acquired after watching the subtitled programmes. This is because it enriches their L2 vocabulary. Furthermore, 14\% of the respondents think that morphology is the linguistic aspect which they developed after watching the programmes. They support their opinion by saying that the subtitles help them to gain knowledge on aspects such as verb agreement and conjugation. This aspect was mostly for English-speaking respondents who have the French language as L2. Concerning syntax, $7 \%$ of the respondents are of the opinion that subtitles provide a good opportunity for learning it. Respondents who chose the last two aspects of pragmatics and phonetics were very few ( 2 and 1 respectively), giving a percentage of $1 \%$ for each. Figure 4 gives an illustration of the findinas.

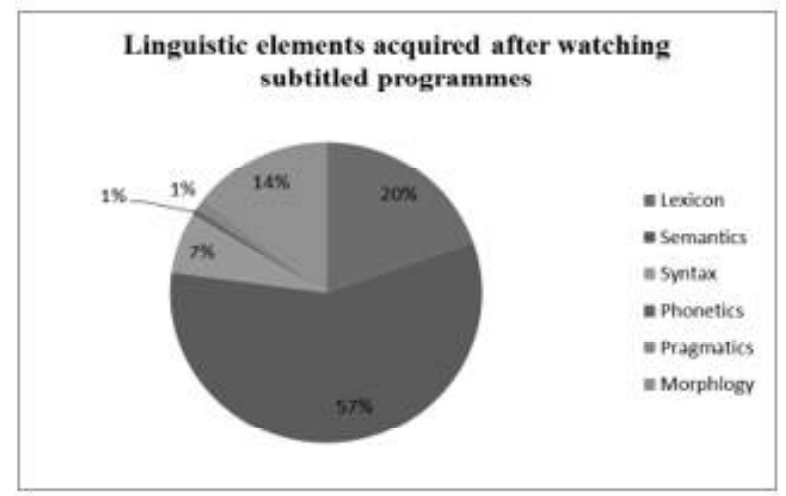

Figure 4: Linguistic elements acquired after watching subtitled programmes [Lexicon (20\%)]; [Semantics (57\%)]; [Syntax (7\%)]; [Phonetics (1\%)]; [Pragmatics (1\%)]; [Morphology $(14 \%)]$

\subsubsection{Do you think watching more of these subtitled programmes can help improve on your second language?}

This question sought to find out if the respondents' watching of these subtitled programmes can help improve on their L2. A great majority of the respondents $(97 \%)$ responded with a "yes", while only $3 \%$ think that the watching of subtitled programmes did not help improve their L2. The respondents who responded with "yes" gave several reasons for their choice. Among which: the subtitles will enhance their spelling and writing skills, the subtitles will help in language acquisition and others said the subtitles will help in improving on their vocabulary. 
3.1.5 Do you think subtitling of TV programmes can help increase the rate of bilingualism in Cameroon?

After knowing the difficulties, the respondents encountered and the skills they developed which were essential to this survey, the researcher also moved on to ask the respondents if it is possible or not for the subtitling of TV programmes in Cameroon to help in increasing the rate of bilingualism in the country.

To this question, $91 \%$ were of the view that it is possible, whereas $9 \%$ of them said that it was not possible.

The respondents' views as to the possibility of increasing the rate of bilingualism in Cameroon through the subtitling of TV programmes in the country diverged from one another. Those who said it was possible supported their answers with the following reasons: Subtitling portrays various elements of language learning such as lexicon, morphology, syntax, semantics and phonetics which are the basic elements of language acquisition. $O$ thers said it could enable them to check difficult words in dictionaries. Some others said they easily retained new words especially when it had to do with music. Others said that when watching a subtitled movie, they had enough time to play and replay which facilitated the learning of a language. Some respondents claimed that when you involve images or objects in a learning process, it becomes easier.

\subsubsection{Choice of preferred programmes for subtitling}

This question sought to find out from respondents the type of programmes which they would like to see always subtitled on TV broadcasting channels in Cameroon. This question was very essential in the sense that it acts here as some kind of "referendum" to inform both decision makers and owners of TV broadcasting channels on the choice of tele viewers in case steps are taken to make the subtitling of some or all TV programmes in Cameroon mandatory. Five kinds of TV programmes were suggested to the respondents to choose from. These programmes are: documentaries, news, talk shows, films and cartoons. The choice of respondents is as follows: documentaries $48 \%$, news $22 \%$, Films $16 \%$, talk shows $10 \%$ and cartoon $4 \%$.

\subsection{Results from interviews}

It should be noted here that the two media houses used in this study do subtitling and equally show subtitled material, about 25\% for CRTV and 15\% for HITV. However, these percentages are far too low compared to that of non-subtitled material showed and taking into consideration the fact that nearly all respondents (99\%) in this study watched these TV stations.

\section{When asked what accounts for the level of the practice of subtitling in both media houses and the attitude of the media houses towards subtitling, while the journalists at CRTV felt that those at the head of the production and in charge of making decisions were most suited to respond and so did not participate. Journalists at Hi TV however told us that they did not have the necessary equipment to do so.}

$\mathrm{N}$ ext, the researcher sought to know if interlingual subtitling is practiced in both media houses (CRTV and Hi TV). All four respondents for CRTV said this type of subtitling is not practiced in their house, whereas all those at $\mathrm{Hi} \mathrm{TV} \mathrm{(100 \% )} \mathrm{said} \mathrm{they} \mathrm{do} \mathrm{interlingual}$ subtitling, but mostly from local languages (especially the Bakweri language) into English, and not from English into French and vice-versa.

When asked if they consider their respective media houses to be completely balanced as far as programmes broadcast is concerned 
for the English-speaking and F renchspeaking audiences, the respondents at CRTV were $100 \%$ unanimous that their media house is balanced in the sense that it broadcast programmes in the English and French language distinctively. The respondents at Hi TV on their part responded that their media house is not balanced since according to them, they are a purely Anglo-Saxon media house and so give priority to their English-speaking audience but they however said that steps are being taken in order to make the French-speaking tele viewers feel included in their programmes. That notwithstanding, the respondents of both media houses were unanimous that almost all existing subtitled programmes are few films imported for broadcast, and with subtitles already done. Besides these, are a few subtitled programmes done by some producers who decide on their own whether or not to use subtitles in their programmes. This is only done where, and if the producers of those programmes deem it necessary.

\section{When asked what is being done to promote balance of information in their respective media houses, their responses were as follows:} 4 respondents at CRTV (100\%) told us that their media house makes extensive use of dubbing in order to enable both linguistic strata get access to the information being broadcast. In their opinion, subtitling introduces an additional component to what is broadcast on screen and it inevitably disturbs the viewer's consumption and appreciation of images, so they rather make use of dubbing than subtitling. The respondents of Hi TV on their part told the researcher that the administrators of Hi TV have plans to make some of their programmes bilingual such as debates and news presentations which will in the near future have two presenters of both French and Englishspeaking backgrounds. An aspect which respondents from both media houses agreed on is that there is no policy at present that governs the use of subtitles and so they are not looking in that direction.

\subsection{Results from observation}

O bservations were made throughout the research study and in particular while carrying out interviews. It was discovered that subtitling is not widely practiced at CRTV or at $\mathrm{Hi} \mathrm{TV}$ and this greatly reflects the state of things in the other media houses in Cameroon, since neither Equinox TV, Canal 2, nor STV etc., carry out interlingual subtitling of their programmes into the two official languages. The lukewarm attitude of these media houses in Cameroon is greatly due to the fact that they already consider their programmes to be linguistically balanced, taking into consideration the expectations of their audience from both linguisctic backgrounds in Cameroon, as most of these media houses alternatively broadcast programmes in English and French.

It can be deduced from the questionnaire results that an increase in subtitling percentages will cause an increase in the improvement of many more and other skills.

Also, there are very few trained translators at CRTV and no subtitlers. The situation is even worse in other media houses that have neither translators nor subtitlers. Hence, audiovisual translators play little, not to say no role, in this audiovisual sector and their absence is greatly felt. Thus, it can be said that translators and subtitlers will be of great impact in the audiovisual sector in Cameroon, especially as concerns the learning of both official languages.

\subsection{Results from documentation}

Results from documentation helped to build up the literature review as well as making comparisons between past studies and the current one. 


\section{Discussion}

\section{A comparison of results from the present} study with those of the 2009 study

This section looks at the current study in comparison with Ayonghe's study (2009). A comparison of these two sets of results (see table 1 below), reveals that although the two studies have as main objective the use of subtitling to promote bilingualism and multilingualism, it is clear that the methodologies used by both studies are different. In 2009, there was no TV station in the South West Region. The current study which is a follow up of the 2009 study, shows that even after 12 years, the volume of subtitling showed over CRTV is still very low and that, very little change has occured since then. However, there is currently a TV station in the South West Region (Hi TV) winch is occasionally broadcasting local dialects with English subtitles.

\section{Major contributions to the field of translation}

This study contributes to translation studies in a number of ways. It:

i. G uarantees media accessibility to the audiences of both linguistic backgrounds in Cameroon and helping them improve on the learning of their second official languages. The fact that the questionnaire respondents improved on understanding and language skills even with low percentages of watching subtitled material, is an indication that, an increase in subtitling percentage of programmes broadcast will cause an increase in the numbers of viewers and thus an increase in media accessibility.

ii. Illustrates how subtitling can better enable tele viewers of both linguistic backgrounds to improve on their writing skills and consequently their performance as well as enable them to participate in nation building and thus, improve on their feeling of belonging and increase their patriotism. iii. reveals that very little subtitling is practiced at CRTV and Hi TV, and throws more light on the reason why this practice is absent in TV and proposes ways to remedy this situation.

iv. highlights the audiovisual translator and subtitler's key roles in the audiovisual sector; roles which CRTV especially and other TV broadcasting houses are not making use of, despite the country's privilege to have well trained audiovisual translators and subtitlers. This was particularly observed at both media houses when the researcher actively took part in the subtitling of some news interviews by their subtitlers.

\section{Conclusion}

This study arose out of the belief that subtitling can be a vector for fostering bilingualism and patriotism in Cameroon. From the data collected and analysed, we can confirm from the results obtained from questionnaires, interviews, observation and documentation that subtitled programmes on Cameroonian TV channels will help viewers learn and acquire their second official languages faster, improve on their language skills, promote bilingualism and this state of bilingualism will in turn instill in the citizens a feeling of belonging and attachment to Cameroon. However, unless a law that will make the subtitling of some, if not all, programmes on Cameroonian TV channels is enacted, the use of subtitling to promote bilingualism will remain ineffective and the dream of seeing a more bilingual Cameroon will continue to be a farfetched one.

\section{References}

Awasom, N. F. (2000). The reunification question in Cameroon history: Was the bride an enthusiastic 
Table 1: Comparison of the results obtained in the present study with those of 2009 study

\begin{tabular}{|c|c|c|}
\hline Pres & t Study & 2009 Study \\
\hline Resu & from questionnaires & \\
\hline & ton -1 & \\
\hline Whil & or the current study, & \\
\hline i. & $\begin{array}{l}\text { A great majority of the respondents }(97 \%) \text { believe } \\
\text { help improve on their second language; }\end{array}$ & d that watching more subtitled programmes could \\
\hline ii. & $\begin{array}{l}\text { Ninety one percent }(91 \%) \text { were of the view th } \\
\text { increase the rate of bilingualism in Cameroon; }\end{array}$ & at the subtitling of TV programmes could help \\
\hline iii. & $\begin{array}{l}\text { The respondents prefer documentaries (48\%) ove } \\
\text { cartoon }(4 \%) \text {. }\end{array}$ & news $(22 \%)$, Films (16\%), talk shows $(10 \%)$ and \\
\hline Resu & from interviews (current study) & Results from interviews (2009 study) \\
\hline $\begin{array}{l}\text { 1. } \mathrm{CF} \\
\text { study }\end{array}$ & $\mathrm{V}$ and $\mathrm{Hi} \mathrm{TV}$ are the media houses used in the & $\begin{array}{l}\text { 1. CRTV, STV } 1 \& 2 \text {, Canal } 2 \text { International and } \\
\text { Equinox TV were the media houses used in the } \\
\text { study. }\end{array}$ \\
\hline 2. Ac & rding to CRTV: & 2. According to CRTV: \\
\hline & $\begin{array}{l}\text { Only top management decides on showing } \\
\text { subtitled programmes. }\end{array}$ & $\begin{array}{l}\text { i. The Cameroonian audience was not } \\
\text { ready for subtitling. }\end{array}$ \\
\hline & $\begin{array}{l}\text { No production of interlingual subtitling } \\
\text { Nonprofessionals for subtitling production. }\end{array}$ & $\begin{array}{l}\text { ii. The broadcast of subtitled programmes } \\
\text { was extremely low. }\end{array}$ \\
\hline & $\begin{array}{l}\text { Extensive dubbed programmes used to strike a } \\
\text { balance between English \& French languages }\end{array}$ & $\begin{array}{l}\text { iii. } \begin{array}{l}\text { Nonprofessionals for subtitling } \\
\text { production }\end{array} \\
\end{array}$ \\
\hline v. & No subtitling policy & iv. No subtitling policy \\
\hline 3. Ac & rding to Hi TV: & \\
\hline & $\begin{array}{l}\text { No equipment for subtitling production } \\
\text { Nonprofessionals for subtitling production. }\end{array}$ & $\begin{array}{l}\text { 3. According to STV } 1 \& \text { \& } 2 \text {, Canal } 2 \\
\text { Intemational and Equinox TV: }\end{array}$ \\
\hline & $\begin{array}{l}\text { Have plans to produce a balance between } \\
\text { English and French programmes later. }\end{array}$ & $\begin{array}{ll}\text { i. } & \text { No broadcast of subtitled programmes } \\
\text { ii. } & \text { Not interested in subtitling at all }\end{array}$ \\
\hline Resu & from observation (current study) & Results from observation (2009 study) \\
\hline Acco & ing to CRTV: & According to CRTV: \\
\hline & No professional subtitlers & i. No professional subtitlers \\
\hline ii. & $\begin{array}{l}\text { Non respect of subtitles norms and thus very } \\
\text { low-quality subtitles }\end{array}$ & $\begin{array}{ll}\text { ii. } & \text { No amateur subtitlers } \\
\text { iii. } & \text { No interest in subtitling }\end{array}$ \\
\hline $\begin{array}{c}\text { Acco } \\
\text { i. }\end{array}$ & $\begin{array}{l}\text { ing to Hi TV: } \\
\text { No professional subtitlers }\end{array}$ & $\begin{array}{l}\text { Only French-dubbed programmes are } \\
\text { broadcast }\end{array}$ \\
\hline ii. & $\begin{array}{l}\text { Non respect of subtitles norms and thus very } \\
\text { low-quality subtitles }\end{array}$ & $\begin{array}{l}\text { v. No balance between the broadcast of } \\
\text { French and English language }\end{array}$ \\
\hline & $\begin{array}{l}\text { I here is production of English subtitles for local } \\
\text { dialects (occasionally). }\end{array}$ & $\begin{array}{ll}\text { programmes } \\
\text { vi. Still planning to start broadcasting } \\
\text { subtitled programmes }\end{array}$ \\
\hline Resu & from documentation (current study) & Results from documentation \\
\hline $\begin{array}{l}\text { Docl } \\
\text { comp }\end{array}$ & $\begin{array}{l}\text { entation used on literature review and } \\
\text { isons between studies. }\end{array}$ & $\begin{array}{l}\text { Extensive documentation was used in the study } \\
\text { since it was qualitative }\end{array}$ \\
\hline Resu & from personal experience & \\
\hline & & ent study. \\
\hline Whil & or the 2009 study: & \\
\hline i. & Bilingualism could be achieved by using (English- & French or French-English subtitles) \\
\hline ii. & $\begin{array}{l}\text { Multilingualism could be achieved by using interli } \\
\text { (English-vernacular) or (vernacular-English). }\end{array}$ & goual subtitles with some of the major vernaculars \\
\hline iii. & $\begin{array}{l}\text { Similarly, intralingual subtitles could be used, } \\
\text { harmonise dialects or languages. }\end{array}$ & the place of interlingual subtitles, to unify and \\
\hline
\end{tabular}


or a reluctant one?. Africa Today, Vol 47, No2, pp. 90-119.

Armstrong, M., Brown, A., Crabb, M., Hughes, C. J., Jones, R. \& Sandford, J. (2017). Understanding the diverse needs of subtitle users in a rapidly evolving media landscape. SMPTE Motion ImagingJaumal. November/ D ecember 2016. Page(s): 33 - 41 http:/ / dx.doi.org/ 10.5594/ JMI.2016.2614919

Ayonghe, L. S. (2009). Subtitling as a Tool for the Promotion of Bilingualism/ Multilingualism in Cameroon. In Tanda, V., Jick, H. K. \& Tamanji, P. N. (eds.), Language, literature and social discourse in Africa Agwecams Publishers, Bamenda, pp. 106-120.

Ayonghe, L. \& Ategha, A. (2018). The power of film translation in Cameroon: Dubbing or subtitling? Intemational Jumal of Engish Language and Trandation Studes 6(4). 40-48.

Ayonghe, L. S., \& Djomo, T. C. (2015). Analysis of the prospects and challenges of subtitling as a mode of audiovisual translation in Cameroon. Journal of Langrages and Culture, 6(7), pp.61-70. è'10.5897/ JLC2015.0326é'. è’hal-01758874é'

Ayonghe, S. L. \& Mbele D. F. (2015). Le rôle du sous-titrage dans la promotion et la valorisation des langues locales au Cameroun. TheTrandation Joumal. URL: http:/ / translationjournal.net/ January-2015/ january-2015.html.

Díaz Cintas J. (2003) Audiovisual trandation in the third millennium In Andeman, G. and Rogers, M. (els), Trandation Today. TrendsandPespeetives MPG Books Ltd, Multilingual Matters, Frankfurt Lodge, Clevedon Hall,Victoria Road, Clevedon, BS21 7HH, England. G reat Britain, pp. 193-203.

Diaz Cintas, J. \& Remael, A. (2007). Subtitling St Jerome Publishing, Manchester.
Grant, A., \& G ottardo, A. (2008). Definingbilingualism Encyclopedia of Language and Literacy D evelopment. $\quad$ http:/ / www.literacyencyclopedia.ca.

Markham,P.L. \& Peter, L.A. (2001). The effects of native language vs. target language captions on foreign language students' DVD video comprehension. Foreign Langrage Amals, Vol 34, pp 439-445

Neves, J. (2008). 10 Fallacies about subtitling for the deaf and hard-of-hearing. Jaumal of Speialised Trandation, Vol 10, pp. 128-143.

Neves, J. (2009). Interlingual subtitling for deaf and hard-of-hearing. In Diaz Cintas, J. \& Anderman G. (eds.), Audiovisual trandation: Language transfer on screen Basingstoke and New York, Palgrave, pp 249-268

Ntowa, T. R. N., \& Ayonghe, L. S. (2015). Audiovisual translation as a tool for teaching English language to French-speaking students in Cameroon. Journal of A frican Studies and Development. Vol.7(8), pp. 200 - 206. https:// doi.org/ 10.5897/ JASD 2015.0355

Tawah, F. F. (2010). 'The potentials and prospects of dubbing and voice-over in Cameroon. Unpublished Masters thesis, Advanced School of Translators and Interpreters, University of Buea.

The Universal D eclaration of Human Rights. The United Nation's Department of Public information (May 2007). New York.

Valdez, G. \& Figueora, R. (1994). Bilingualism and testing: A special case of bias. Norwood, NJ: Ablex. Pp. 255-265. Volume 21 Issue 2. Vulchanova, M., Saldaña, D., Chahboun, S., \& Vulchanov, V. (2015). Figurative language processing in atypical populations : the ASD perspective. Fronties in human nerrosaience 9, 24. https:/ / doi.org/ 10.3389/ fnhum.2015.00024 